\title{
THE HYDROLOGICAL INFLUENCE OF FOREST HARVESTING INTENSITY ON STREAMS: A GLOBAL SYNTHESIS WITH IMPLICATIONS FOR POLICY
}

\author{
FAROOQI, T. J. A. ${ }^{1 *}-$ ABBAS, H. $^{2}-$ HUSSAIN, S. ${ }^{3}$

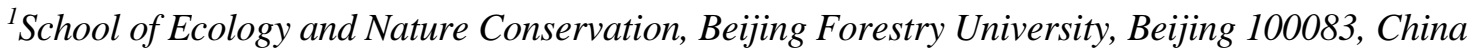 \\ ${ }^{2}$ College of Forest Science, Beijing Forestry University, Beijing 100083, China \\ ${ }^{3}$ Research Center of Forest Management and Engineering of National Forest and Grassland \\ Administration, Beijing Forestry University, Beijing 100083, China \\ *Corresponding author \\ e-mail: tanzeelfarooqi_21@yahoo.com
}

(Received $4^{\text {th }}$ Feb 2020; accepted $22^{\text {nd }}$ May 2020)

\begin{abstract}
The hydrological properties of the clearcutting of forested catchments were widely investigated by analyzing runoff in the pre- and post-harvesting periods. Deforestation worldwide is primarily to meet the wood and fiber products demand for household and industry. It is a widely known phenomenon that deforestation enhances the streamflow and water yield. However, due to the complexity of forest structure and functions, little is known about the exact estimation of a percent increase in water yield after various harvesting intensities of conifers and broadleaved forest globally. To assess these effects, this study analyzed 145 catchments dataset collected from 21 publications. The study evaluates the influence of 25 , 50,75 , and $100 \%$ deforestation on streamflow. Moreover, changes in the context of various variables like treatment years, elevation, area and mean annual precipitation were also analyzed. Overall comparison showed that after harvesting of broadleaved water yield increases up to $8-23 \%$ and in needle-leaved up to 9-28\%. The study provides scientific insight into the essential role that annual precipitation, area, elevation, and year of treatment play in influencing hydrology. This research suggests that a target specific approach should be adopted in future forest management under the umbrella of integrated research to mitigate the challenges of climate change.
\end{abstract}

Keywords: climate change, streamflow, annual precipitation, water yield, broadleaved, needle-leaved

\section{Introduction}

The ever-increasing trend in the human population has caused an upsurge the overexploitation of natural resources, especially the degradation of forests in terrestrial ecosystems. Forests are essential to life on Earth, providing numerous ecosystem services (Costanza et al., 1997) such as fruits, honey, oil, pickle, biocontrol, pollination, Carbon sink, water, and nutrient recycling as well as biodiversity conservation (Nasi et al., 2002; Badshah et al., 2017; Wang et al., 2017; Masiero et al., 2019; Ullah et al., 2019b; Muhammad et al., 2020). Among all the forest ecosystem services, carbon sinks and water provision to down- stream are the two primary services which act as essential cogs in the carbon and water cycle by playing their active role in forest processes and functions. However, there are some trade-offs between gain in forest productivity and ecosystem water balance (Farooqi et al., 2019b). Due to brimming of the population in the world has led to an increase in anthropogenic disturbance which are the primary cause of changes in forest composition over a period characterized by drastic changes in both land use and cover resulting increase in fossil fuel emissions and influencing environmental condition (Law et al., 2002; Houghton, 2012; Siddique et al., 2020). This situation is getting worst in 
developing countries because of massive deforestation and fire incidences (Khan et al., 2019; Ullah et al., 2019a; Ali et al., 2020).

Despite all the conflicting debates on retaining and removing forests (Popkin, 2019), for sequestrating carbon which enhances productivity, it is overwhelmingly considered the top priority (Krankina et al., 1997; Ruddell et al., 2007). As far as their interaction with water is concerned in this modern era, forests are also recognized in two important terminologies "upstream" as a source of water in streams and rivers (Zhang et al., 2017), and "upwind" as a source of precipitation (van der Ent et al., 2010; Ellison et al., 2012, 2017) however, these trends are bound to the localities and regions.

Deforestation is mainly considered as a positive aspect of increasing the streamflow and runoff, which is ultimately utilized by the industry and household (Bosch and Hewlett,1982; Jones and Post, 2004). Meanwhile, the expansion of forests reduces this water flow leading to $52 \%$ of half dryness and $13 \%$ of complete dryness of streams in the world (Andréassian, 2004; Jackson et al., 2005). The result is decline in water availability to downstream users (van Dijk and Keenan, 2007), especially dry areas are more vulnerable to this situation. However, the phenomenon of annual runoff is generally dependent on annual precipitation and evapotranspiration. The greater the precipitation, the less evapotranspiration will ultimately enhance runoff and vice versa (Komatsu et al., 2011). The proportionate contribution of precipitation to streamflow varies by how interception and evapotranspiration are influenced by vegetation development stage, rooting depth and health. However, this may differ widely according to vegetation type (Calder, 1999; Zhang et al., 2001). Because the main components of evapotranspiration are canopy transpiration and interception loss (Van Wijk et al., 2001; Vertessy et al., 2001; Wilson et al., 2001). Interception losses from coniferous and broadleaved forests were presented by (Huber and Iroume, 2001; Komatsu et al., 2011), depending on rainfall and forest characteristics (Iroume and Huber, 2002).

In the past, many research investigations have evaluated the effect of logging operation on the global variation in water yield depending on different forest types and structure (Hornbeck et al., 1993; Troendle et al., 2001; Andreassian, 2004; Adams and Flower, 2006; Komatsu et al., 2011), especially the impacts of forest harvesting of broadleaves and conifers forests on runoff and water yield (Komatsu et al., 2011). Yet questions and misconceptions linger regarding the influence of forest harvesting operations on streamflow under the variety of climatic, physiographic factors, and forest management constraints. It has been shown that considerable change in streamflow after forest cutting can be observed when more than $20 \%$ of the forest cover declined (Stednick, 1996). However, many previous studies of broadleaf and conifers forests reported that the annual runoff improved by $10-70 \%$, depending on the size of the harvesting intensity (Keppeler and Ziemer, 1990; Fahey, 1994; Swank et al., 2001; Farooqi et al., 2020a). Similarly, some reported the effects of timber removal only in the first years after final harvest (David et al., 1994; Bari et al., 1996), whereas, others investigated up to 6-23 years after the event (Ruprecht and Stoneman, 1993; David, 1994; Fahey, 1994). This variation in results widely depending on forest type, harvesting technique, climate as well as the topography of the area.

Although forest harvesting has positive impacts on streamflow and water yield, it also has many adverse implications on the whole ecosystem. Therefore, predefined knowledge about forest types can be helpful for understanding and implementing afforestation/deforestation programs in the context of minting the balance between forest carbon sequestration and water conservation. This will provide future assistance to regional forestry planning and forest management. In this case, the negative influences of forest on 
streamflow might be to control the proportion of forest cover at the catchment scale, which has the potential to modify the streamflow regime (Zhang et al., 2012). This fact is essential to get a better understanding of the affiliation between runoff concerning forest cover proportion (Brown et al., 2013).

To satisfy the rapidly increasing burdens on water supply and other ecosystem services, a practical approach for managing forests (afforestation/deforestation) is needed to achieve the multifunctional benefits. That mainly addresses the tradeoff between carbon sink and water yielding, which is urgently required (Fig. 1). The present article aimed to investigate the effects of various degrees of deforestation on the hydrological properties of different streams with forested catchments, as well as the influence of precipitation afterward.

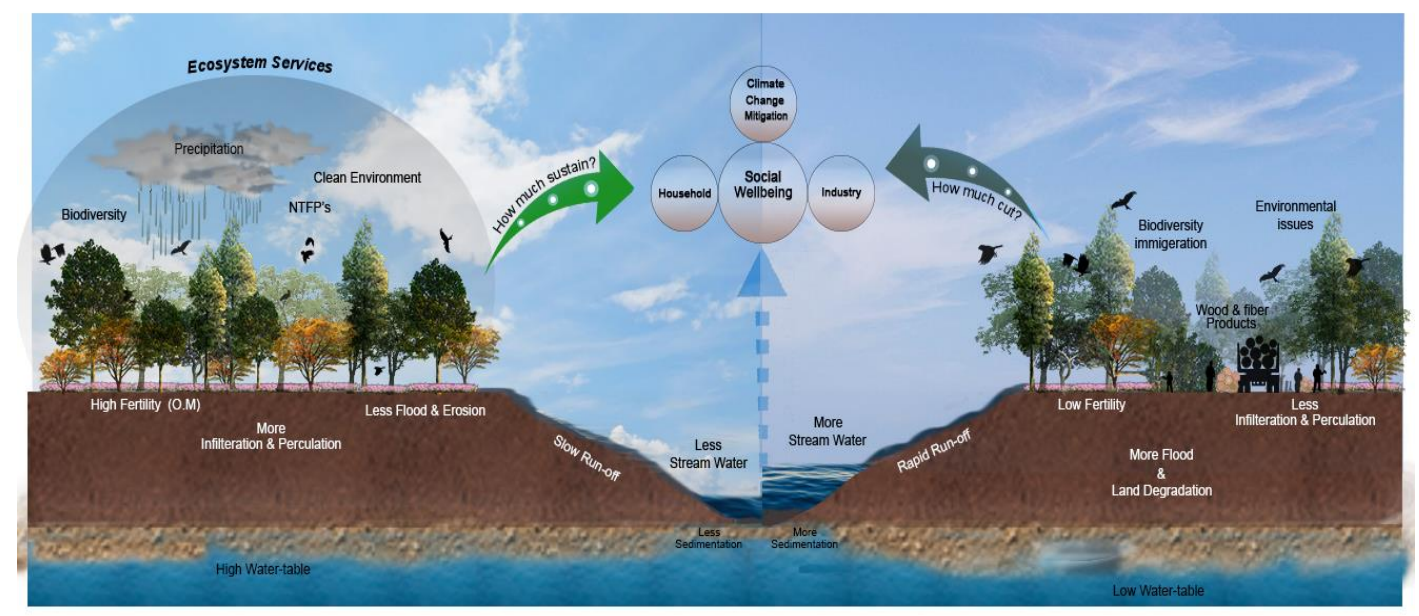

Figure 1. The diagram showing the importance of retaining and removing forest, and their overall impacts on socio-economic development under the umbrella of efficient forest management strategies for climate change mitigation

\section{Materials and methods}

\section{Data collection and processing}

We have compiled this large dataset of deforestation studies and their impacts on water yield from research articles published peer review journals. The sample consists of total of 64 watershed sites of conifers forest stand and 81 sites belonging to broadleaf forest stand, totaling 300 observations from all over the world. This study compiled the dataset from 21 peer-reviewed journals as well as reports of governmental and nongovernmental research institutes, representing many parts of the world (Appendix 5). The forest types were classified into conifers and broadleaf depending upon the dominant species of the forest stand as well as information available in the publication. Information gathering included deforestation intensities on water yield and streamflow before and after treatment. Elevation, age, area, yearly record after treatment and mean annual precipitation were determining from the publication for each site. All those sites which showed no significant increase in water yield after harvesting were discarded to get reliable and expressible estimate of computed harvesting intensities of $25,50,75$ and $100 \%$. The harvesting intensities were set according to the previous researches guidelines i.e. considerable change in water yield after harvesting was mainly observed when $20 \%$ or more area was cut (Bosch and Hewlett, 1982; Stednick, 1996). The percent change in water yield after harvesting was computed with the help of formula as shown in Equation 1. 
Change in water yield $(\%)=\frac{\text { Increase in water yield after treatment }}{\text { Total available water in stream before and after treatment }} * 100($ Eq. 1$)$

*where stream water before and after treatment in equation. 1 is in $\mathrm{mm}$

\section{Testing of significance}

First the Normality test i.e. Shaprio-wilk test was performed, this test showed that the conditions of normality and homogeneity of variance were not met and that has been visual represented in QQ plot. Later nonparametric Kruskal-Wallis tests were applied before by Farley et al. (2005) in a kind of synthesis analysis. In each case, the dependent variable was either the proportional change in water yield following change in factors of evaluation i.e. deforestation percentage. The significance test suggests that the water yield rate is not the same in each of the two or more harvesting intensities $(\mathrm{P}<0.05)$. Even if we rejected the null hypothesis of no difference, the test does not tell us either the two similar intensities of broadleaved and needle-leaved differ significantly from each other. To compare two groups at a time used the Wilcoxon Rank test.

\section{Results}

The results of Shaprio-wilk test rejected normality at $\mathrm{P}<0.0001$ (Appendix 1); the results of the QQ plot showed the visual representation, i.e., the distribution of variables for conifers and broadleaves forest groups of all four harvesting intensities. Many points in both ends fall out of the line and are away from the confidence envelope (Appendix 2). Similarly, the Kruskal-Wallis test showed a highly significant increase in streamflow (\%) after deforestation in broadleaved and conifers forests of the global dataset at $\mathrm{P}<0.0001$ as mentioned in Appendix 3. These results reveal that the percent increase in water yield after treatment of 25, 50,75, and $100 \%$ harvesting intensities in the broadleaved forest was 8,15 , 20 , and $23 \%$, respectively. However, this increase was significantly higher in conifers than broadleaved with increase of 9, 17, 23 and $28 \%$ in water yield respectively (Figure 2). Therefore, the overall results of needle-leaved are significantly higher than broadleaved forest stand after treatment as illustrated in Appendix 3. Similar results have shown from Wilcoxon rank test while comparing similar harvesting intensities of both the forest vegetation types at $(\mathrm{P}<0.05)$ in $($ Appendix 4$)$.

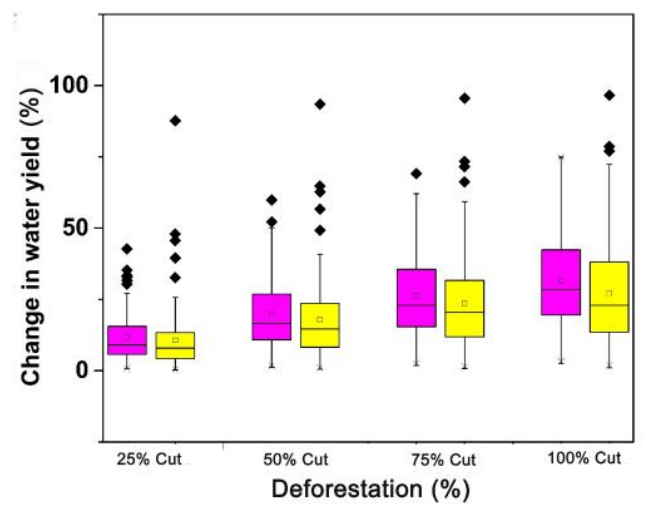

Figure 2. Results showing the percent increase in water yield after different harvesting intensities in broadleaved and needle leaved forests of the world at $P<0.05$. (Yellow color indicating broadleaved and pink representing needle-leaved forest) 
The relationship between annual precipitation and change in water yield $(\mathrm{mm})$ as well as an increase in water yield (\%) after harvesting is shown in Figure 3. The results showed that in higher annual precipitation regions $(>1000 \mathrm{~mm})$, streamflow in $\mathrm{mm}$ also increased more than in lower annual precipitation regions $(<1000 \mathrm{~mm})$. However, the post-harvest increase in percent change of water yield was higher in the low rainfall area than in high precipitation regions.

The regression analysis in Figure $4 a$ and $b$ also demonstrated this relationship. The figure illustrated that as long as the annual precipitation $(\mathrm{mm})$ is increasing, the water yield or streamflow $(\mathrm{mm})$ after the treatment also increasing with positive linear trend of $\mathrm{R}^{2}=0.35$ at $\mathrm{P}<0.0001$ (Fig. 4a). Similarly, the relationship between annual precipitation $(\mathrm{mm})$ and percent increase in water yield or increase in streamflow $(\%)$ after treatment showed declining trend with $\mathrm{R}^{2}=0.10, \mathrm{P}<0.0001$ (Fig. 4b), indicating that the percent increase in water yield after treatment was observed from low precipitation to high precipitation regions.

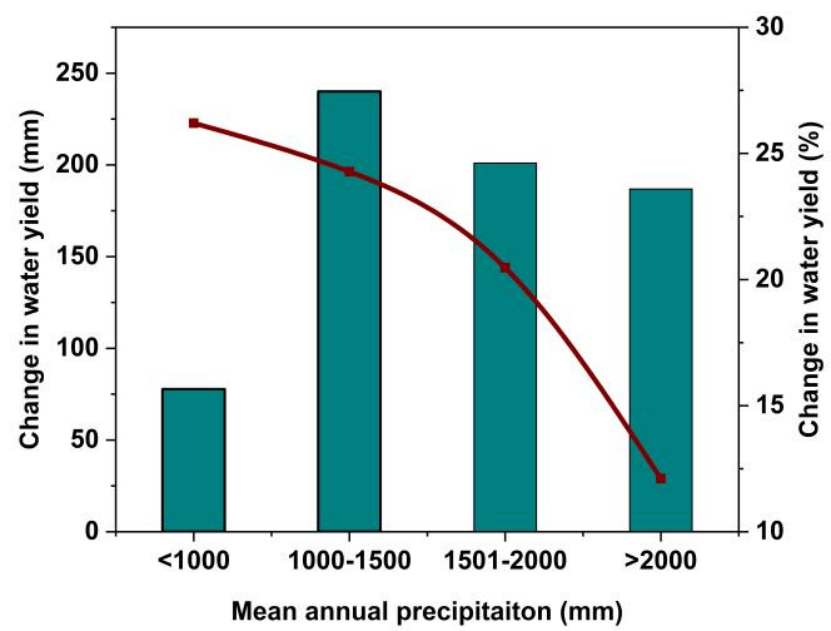

Figure 3. Representing the influences of annual precipitation on change in water yield $(\mathrm{mm})$ and percent change in water yield (\%) after harvesting of the study sites (Green bars are representing Change in water yield ( $\mathrm{mm})$, brown line showing Change in water yield (\%)
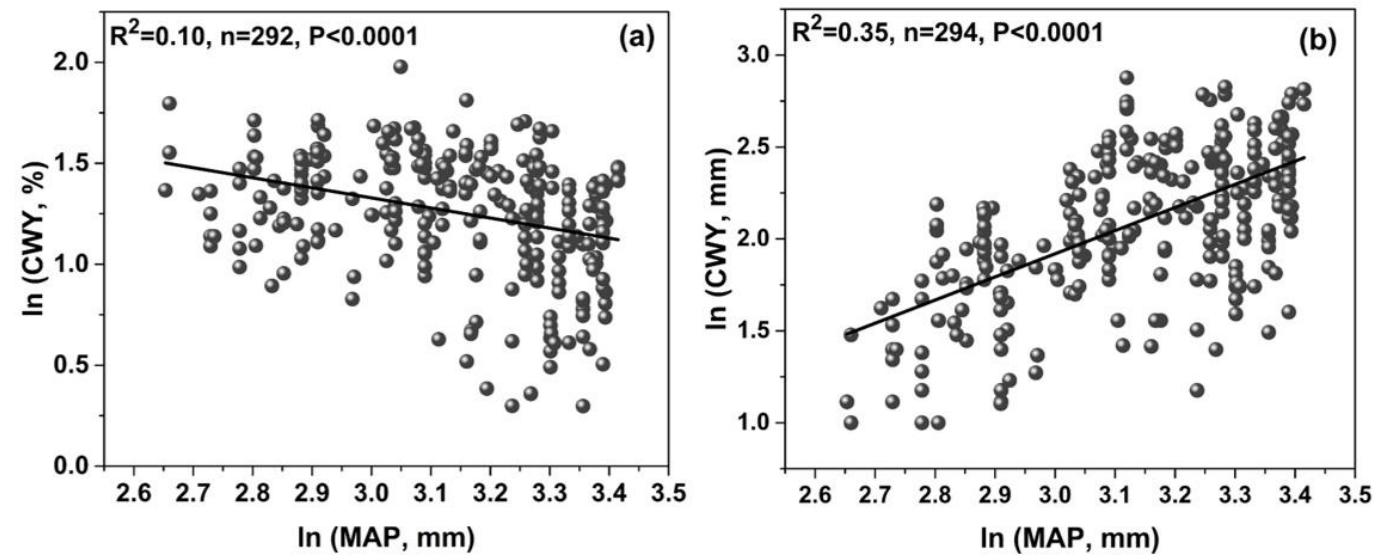

Figure 4. Illustrating the log transformed linear relationship between mean annual precipitation $(\mathrm{mm})$ and change in water yield $\mathrm{CWY}(\mathrm{mm})$ and percent change in water yield $C W Y(\%)$ after treatment of global catchment sites. (MAP-mean annual precipitation) 
To further explain, the role of forest types and their interaction with annual precipitation and change in water yield after treatment was assessed in Figure 5. The figure indicated that the majority of the broadleaved forests of this study belong to high precipitation areas than needle-leaved forests.



Figure 5. Representing the presence of needle-leaved (NL) and broadleaved (BL) forests observations taken from different precipitation regions of the world in dataset of our study

Similarly, in the dataset majority of the bigger catchment $(<150 \mathrm{ha})$ with higher elevation $(<2500 \mathrm{~m})$ were found in lower precipitation regions $(>1000 \mathrm{~mm})$ as shown in Figure 6.

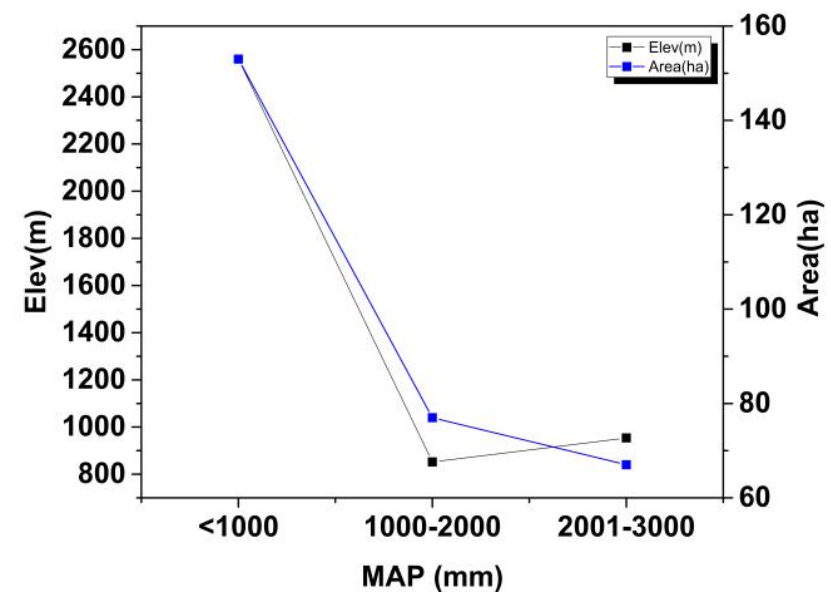

Figure 6. Showing the distribution of mean annual precipitation $(\mathrm{mm})$ at different elevation and forest cover areas of study sites. (MAP-mean annual precipitation)

As far as post-treatment regrowth and recovery of vegetation are concerned, the broadleaf showed significant declining trend at $\mathrm{P}<0.0001$, however these results are non-significant in case of needle-leaved the forests as represented in Figure $7 a$ and $b$. 



Figure 7. Illustrating the relationship between year after treatment and increase in streamflow (\%) of global catchment sites. (NL-needle-leaved, BL-broadleaved forest)

The change in water yield/streamflow after harvesting in $\mathrm{mm}$ decrease from lower to higher elevation level ( $<1000$ to $3000 \mathrm{~m}$ ). However, the percent increase in streamflow after harvesting showed an increasing trend from a lower elevation to higher $(<1000$ to $3000 \mathrm{~m}$ ), as shown in Figure 8.

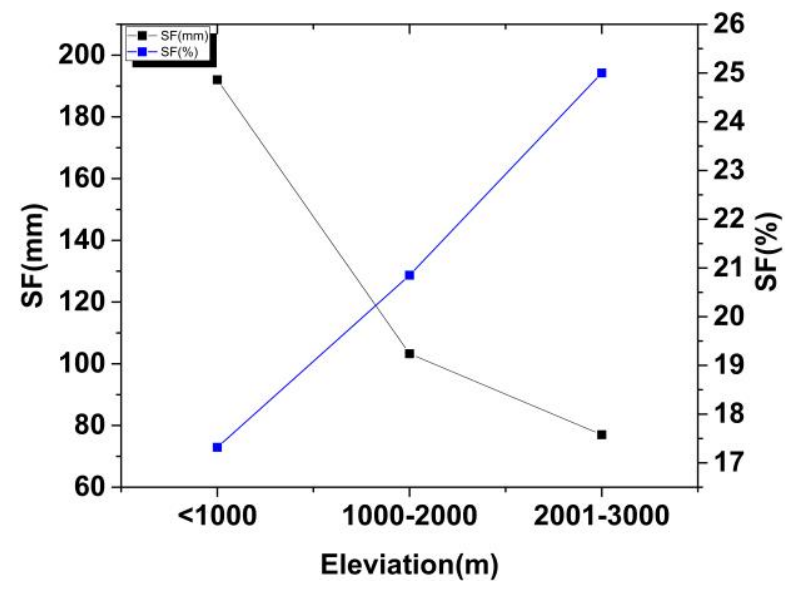

Figure 8. Showing the trend of increase in streamflow $(\mathrm{mm})$ and percent increase in streamflow (\%) after harvesting at different level of elevation. (SF-streamflow)

Similarly, in the forest area less than or equal to 100 ha showing $20 \%$ increase in streamflow after harvesting, but this trend was at its peak in forest cover of 101-300 ha with maximum percent increase in SF of around 26\%, afterword > 300 ha indicating abrupt decline in percent increase of SF up to (18.2\%). This is also worth noted that change in water yield in $\mathrm{mm}$ is greater $(220 \mathrm{~mm})$ in the forests consisting of < 100 ha area followed by decline up to $65-100 \mathrm{~mm}$ in forest cover of 101-300 ha land as shown in Figure 9. 




Figure 9. Showing the trend of increase in streamflow $(\mathrm{mm})$ and percent increase in streamflow (\%) after harvesting at different forest cover area (ha). (SF-streamflow)

\section{Discussion}

\section{Forest types and hydrology}

On a global level, there is a significant research gap about exact identification of the increase in water yield $(\%)$ and streamflow $(\mathrm{mm})$ of different forest harvesting intensities. However, mixed results of varying harvesting intensities have found in previous research investigations (Bosch and Hewlett, 1982; Hornbeck et al., 1993; Stednick, 1996; Troendle et al., 2001; Pike and Rob, 2003; Andreassian, 2003; Adams and Flower, 2006; Komatsu et al., 2011). The plausible reason behind this variability might be due to different site/location, climate type, vegetation type, forest structure, origin, stand age, treatment years, harvesting technique, season of treatment, soil as well as other methodological and technical constraints. The results of this analysis indicated that needle-leaved forest has resulted a greater change in water yield (\%) after harvesting than broadleaved when compared to different forest harvesting intensities of $25-100 \%$. This increase in water yield of broadleaved was (8-23\%) and needle-leaved (9-27\%) after treatment is shown in Figure 2. In the previous research investigations, it was indicated that the considerable change in streamflow after timber harvesting occurred when more than 20\% of the forest cover was reduced (Bosch and Hewlett, 1982; Stednick, 1996). However, phenomenon has contradicted and reveals that in some of the catchment studies, lesser harvesting intensity has had measurable increases in water yield than the area with $100 \%$ harvest depending on the catchment site and topographic factors. For example, with $15 \%$ of the basal catchment area could be cut for a considerable upsurge in annual water yield at the catchment scale in the Rocky Mountain region, whereas 50\% in the Central Plains, although system responses are variable (Stednick, 1996). Similarly, the results from previous studies are also in accordance with the findings of this study indicating that the influence of different harvesting intensities on percent change in water yield is higher in needle-leaved than broadleaved forest. A recent global synthesis indicated that $68 \%$ removal of broadleaved forest leads to increase of just 16\% of stream flow (Farooqi et al., 2020a). Another regional study in New Zealand showed that native deciduous forest clearfelling caused average increase of $70 \%$ on five years of treatment (Fahey, 1994) on the 
other side in a southern Appalachian Mountains (USA) 59 ha of mixed hardwood stand clearcutting enhanced streamflow just $28 \%$ after the first year of treatment (Swank et al., 2001). In two catchment studies in Australia one was patch-cut to remove $22 \%$ of basal area of Wicksend catchment, and the Willbob catchment was thinned to remove $12 \%$ of basal area of eucalyptus forests. This caused an annual increase in streamflow by $10 \%$ in the first three years after logging at Wicksend, and by $31 \%$ for the first four years at Willbob (Lane and Mackay, 2001).

Consequently, mixed results have recorded in case of needle-leaved deforestation. For example, the removal of 14 million board feet of lodgepole pine (Pinus contorta) from about 25 percent of the Brownie Creek basin formed an average of $147 \mathrm{~mm}$ extra water yield per annum, which is equal to $52 \%$ of the increase in annual water yield (Burton, 1997). The study of continental/maritime hydroclimatic regions of the United States in naturally regenerated conifers stands after 50\% clear cut and $50 \%$ partial cut treatments reported increased water yields of $270 \mathrm{~mm}(36 \%)$ and $140 \mathrm{~mm}(23 \%)$ respectively (Hubbart et al., 2007). Similarly, a global study revealed that with $71 \%$ deforestation of needle leaved forests caused an increase of $27 \%$ in water yield in down streams (Farooqi et al., 2020a). These results agreed that in needle-leaved forest of large coverage $>2000$ ha might produce significant or drastic increase in water yield and increase the risk of severe flooding (Burton, 1997).

\section{Forest types and precipitation}

Annual precipitation impacts the scale of water yield intensifications that follow timber harvest operations in forested watersheds (Keppeler and Ziemer,1990; Brown et al., 2005; Adams and Fowler, 2006; Komatsu et al., 2011). The results in this study indicated the significant increase in annual streamflow $(\mathrm{mm})$ in higher precipitation areas compared to lower regions of the world as shown in Figure 2 and the linear trend in the relation between annual precipitation and increase in streamflow $(\mathrm{mm})$ is recorded in Figure $3 b$. This shows that the plantation schemes can be successful established in high precipitation region in order to achieve carbon objectives because abundance of water in these regions will not only helpful in enhancing the growth and productivity but also atmospheric circulation. Similarly, the percent increase in water yield after harvesting is lower than in low precipitation regions of the world (Figs. 2 and $3 a$ ), because the water available in the region is already in sufficient quantity, therefore after harvesting big change even show little difference. Moreover, the more evaporative losses can act positive in enhancing precipitation having sufficient energy to lift the additional atmospheric moisture high enough to condense and form clouds (Jackson et al., 2005). However, the precise estimation of hydrological implications of large watersheds (> $1000 \mathrm{~km} 2$ ) are largely lacking due to more complex for structure and other confounding factors.

It is also worth noting that in this dataset majority of vegetation at comparatively lower precipitation regions is needle-leaved compare to broadleaved found in higher precipitation regions (Fig. 5). A recent past, Farooqi et al. (2020a) highlighted the influences of precipitation on percent increase in water yield after-harvesting in broadleaved and conifers forests, however, he did not elaborate on these impacts and their causing factors. The reason behind all of these results might be vegetation affects the proportion of precipitation that is evaporated and transpired and, consequently, the amount available for soil moisture storage, groundwater recharge, and dry weather streamflow of broadleaved and needle-leaved forests (Komatsu et al., 2011). The 
variation in transpiration in the forests is because of the leaf area index as well as stomatal conductance (Kelliher et al., 1995; Raupach, 1995), whereas the interception losses also vary according to leaf area index (Komatsu et al., 2008; Muzylo et al., 2009). These interception losses were thoroughly discussed in the previous research investigations of coniferous and broadleaved forests (Huber and Iroume, 2001; Komatsu et al., 2011), while Iroume and Huber (2002) demonstrated that there are many factors associated with these losses influenced by rainfall and forest characteristics like species, density, age, etc. It is generally believed that the streamflow response depends on the mean annual precipitation of the area (Bosch and Hewlett, 1982; Ruprecht and Stoneman, 1993; Iroumé et al., 2000). Increases in streamflow (mm) are generally most significant in areas of high rainfall, but they are short-lived due to rapid regrowth of vegetation (Bosch and Hewlett, 1982; Ruprecht and Stoneman, 1993; David, 1994; Fahey, 1994; Swank et al., 2001). The decreasing trend toward pre-disturbance levels is of interest because regeneration has been reported in diverse environments, silvicultural and forest species dominance (Fahey, 1994; Bosch and Hewlett, 1982; Cornish, 1993; Hornbeck et al., 1993). For example, reductions in streamflow below pre-disturbance levels have been observed as isolated cases in needle-leaved evergreen planted a forest of the temperate region in southern Chile. Indicated that the $120 \%$ increase in runoff might be partly due to the higher rainfall during the post-harvesting period (Iroumé et al., 2006). Another study on the jarrah forest in south-western Australia reveals that the subsequent recovery of vegetation cover has led to water yields returning to predisturbance levels after an estimated 12-15 years (Ruprecht and Stoneman, 1993). The deciduous conversion to pine, forest harvesting in moderate-to-high rainfall areas causes a $60-80 \%$ increase in water yield for three-five years after clear-felling. It was also noted that the yields should return to pre-harvesting levels within six-eight years, depending on the silvicultural regime adopted (Fahey, 1994).

In the present study results, the significant decline trend in water yield $(\mathrm{P}<0.0001)$ after the first year of broadleaved forests removal till it reaches to the pretreatment stage as shown in Figure 6 might be connected to their coppiced nature which might be the reason for rapid regeneration after deforestation. For example, in a study conducted in Central Portugal, when a coppicing a fast-growing species of eucalyptus due to the fast regrowth of the forest stands recorded that the hydrological effects of clearcutting were short-lived (David,1994), in Coweeta, a mature hardwood coppice stand the first cutting required 23 years' recovery time to reach pretreatment level in striking contrast the second cutting achieved this level just within 16 years (Swank et al., 1970). Therefore, water use strategies were developed according to the variation in developmental stages as well as the available water resources (Su et al., 2014). The result of these studies demonstrate that annual water yield increases obtained from complete forest cutting in coppice catchment can be more short-lived in second rotation. Because of the difference in basal area, LAI, species density as well as letter fall production of first stand enhances fertility and water retention in the soil, which boost the regrowth of second cutting. Moreover, the only way forward of gaining large increase in annual water yield is to manage regrowth and control dense sprouting and rapid crown development.

\section{Forest types and water use}

The main distinction between the percent increase in water yield after harvesting in conifers versus broadleaved as shown in Figure 2 might be due to the efficient water use of broad-leaved than in conifers. Evergreen conifers tend to have a higher water use 
due to high interception losses which are maintained throughout the whole year, and particularly during the winter period when conditions are usually wettest and windiest. During the vegetative period, interception rates are also often higher in conifer stands because of more leaf area indices. The differences are most pronounced during the dormant season when interception rates are low in hardwood stands. For example, two studies in the European forests have found that average yearly interception rates are around $25 \%$ for broadleaves species and about $45 \%$ for coniferous species (Augusto et al., 2002; Calder et al., 2003).

Canopy transpiration is often thought to increase asymptotically with leaf area index (L) for a species (Meinzer and Grantz, 1991; Raupach, 1995; Arneth et al., 1996; Oren et al., 1996). It was assumed that annual transpiration does not differ considerably between broadleaf and coniferous forests (Roberts, 1983; Harding et al., 1992; Cannell, 1999). Large-scale afforestation resulted a rise in evapotranspiration, hence dropping instream flows (Farley et al., 2005; Sun et al., 2006, 2008), therefore impacting the effectiveness of water conservation strategy of plants at leaf or individual level. Quantifying the productivity-water loss tradeoffs at the ecosystem level is the primary parameter to analyze the carbon-water relationship in different forest types ( $\mathrm{Li}$ et al., 2019). Many studies at ecosystem level have demonstrated that broadleaved forest have higher productivity and less water loss than needle-leave forests (Tan et al., 2015; Gower et al., 2001). This might be because deciduous leaves have higher rates of photosynthesis per unit leaf mass during favorable conditions than evergreens, given their higher leaf nitrogen content and specific leaf area, higher intrinsic photosynthetic capacity, and the reduced internal competition for light and carbon dioxide (Catovsky et al., 2002). For example, deciduous oaks compensate for having a shorter growing season by attaining a higher capacity to assimilate carbon for a given amount of intercepted solar radiation during the well-watered spring period. At saturating light levels, deciduous oaks gained carbon at six times the rate of evergreen oaks (Baldocchi et al., 2010).

This water utilization behavior of the broadleaf and conifers may directly and significantly impact the hydrology and water yield of the forest. For example, the first study (Swank and Douglass, 1974) to examine differences in annual runoff and evapotranspiration (ET) between broadleaf and coniferous forests was performed in the United States using the paired-catchment method. Annual flow decreased with the conversion from broadleaf to coniferous forest. Changes in yearly runoff due to vegetation changes indicate changes in annual ET. Thus, the results indicate lower annual ET for broadleaf forests than for coniferous forests, suggesting that the presence of broadleaf forests is more beneficial from the viewpoint of water availability in downstream. In another study, long-term records of streamflow following the conversion of hardwood stands to conifers show reduced water yield (Hornbeck et al., 1997; Komatsu et al., 2009). For example, this trend has been instigated in Japan (Komatsu et al., 2009). More extensive evidence of the lower annual evapotranspiration for broadleaf forests compared to coniferous forests was provided by surveying the results of numerous paired-catchment studies (Bosch and Hewlett, 1982). A very latest survey of a global dataset also demonstrated that ET of broadleaf forests is lower than coniferous, resulting in a higher annual runoff for broadleaf. The study also suggested that this condition is only valid for broadleaf deciduous forests (Komatsu et al., 2011). The differences between conifers and deciduous trees are often incorporated into large-scale models because of differences in xylem anatomy (vessels versus tracheids), leaf 
longevity, leaf area index, and growing season (Roberts and Rosier, 2005). Therefore, from all these survey results it is concluding that the increase in annual runoff due to deforestation tended to be lower of broadleaf forests than coniferous forests, which suggests the generality of the yearly ET for gaining growth and productivity of broadleaf forests is lower than coniferous forests.

\section{Conclusion}

In the past, many afforestation projects were established without knowing their carbon and water interaction. The difference of change in water yield (\%), as well as an increase in streamflow $(\mathrm{mm})$ after harvesting of broadleaved and needle-leaved forest in low and high precipitation regions, along with other adjoining factors are giving us a clue as to how the future afforestation policy needs to be revised. When, where, and why to plant/cut the tree is important questions to address. The results showed that needle-leaved forests in lower precipitation regions are expected to consume more water than broadleaved in higher rainfall regions. This study can speculate from these results that afforestation and conversion of broadleaved to conifers or mixed in higher precipitation regions might be more useful to get maximum productivity. Conversely, in lower precipitation regions scattered plantation of broadleaved primarily deciduous species along with shrubs and grasses might be an option to maintain the carbon and water tradeoff of global forests. However, sustainable forest management and targeted planning for establishment of future plantations need to take into account a broader prospective of multifunctional objectives is prerequisite to mitigate the future challenges of climate change.

Acknowledgements. TJA Farooqi acknowledges the financial support of the China Scholarship Council and Ministry of Science and Technology of China (Grant No. 2016YFC0502104). Author would also like to thank Miss. Fionnuala McCully, from School of Environmental Sciences, University of Liverpool, UK for her valuable suggestions and improvement for the manuscript. Author would also to thanks Mr. Muhammad Amir Siddique from School of Landscape Architecture, Beijing Forestry University, 100083, Beijing, China for his help in drawing Figure 1 on photoshop software and fruitful suggestions.

Conflict of Interests. Authors declare that there is no conflict of interests.

\section{REFERENCES}

[1] Adams, K. N., Fowler, A. M. (2006): Improving empirical relationships for predicting the effect of vegetation change on annual water yield. - Journal of Hydrology 321: 90115. https://doi.org/10.1016/j.jhydrol.2005.07.049.

[2] Ali, T., Gulzar S., Arroj, S.S., Muhammad, B., Ullah, F., Ahmad, N., Ullah, S (2020): Integrating spectral indices, topographic factors, and field data into detecting post-fire burn severity. Bulletin of the Transilvania University of Braşov Series II. 13(62):1 (In press)

[3] Anderson, H. W., Hoover, M. D., Reinhart, K. G. (1976): Forests and water: effects of forest management on floods, sedimentation, and water supply. - General Technical Report PSW-018. Berkeley, CA. US Department of Agriculture, Forest Service, Pacific Southwest Forest and Range Experiment Station 115: 18.

[4] Andréassian, V. (2004): Waters and forests: from historical controversy to scientific debate. - Journal of hydrology 291: 1-27. https://doi: 10.1016/j.jhydrol.2003.12.015. 
[5] Arneth, A., Kelliher, F. M., Bauer, G., Hollinger, D. Y., Byers, J. N., Hunt, J. E., McSeveny, T. M., Ziegler, W., Vygodskaya, N. N., Milukova, I., Sogachov, A. (1996): Environmental regulation of xylem sap flow and total conductance of Larix gmelinii trees in eastern Siberia. - Tree Physiology 16: 247-255.

[6] Badshah, M., Ahmad, A., Muneer, M., Rehman, A., Wang, J., Khan, M. (2017): Evaluation of the forest structure, diversity and biomass carbon potential in the southwest region of Guangxi, China. - Applied Ecology and Environmental Research 18(1): 447-467.

[7] Baldocchi, D. D., Ma, S., Rambal, S., Misson, L., Ourcival, J. M., Limousin, J. M., Pereira, J., Papale, D. (2010): On the differential advantages of evergreenness and deciduousness in Mediterranean oak woodlands: a flux perspective. - Ecological Applications 20: 1583-1597.

[8] Bari, M. A., Smith, N., Ruprecht, J. K., Boyd, B. W. (1996): Changes in streamflow components following logging and regeneration in the southern forest of Western Australia. - Hydrological Processes 10: 447-461.

[9] Bent, G. C. (2001): Effects of forest-management activities on runoff components and ground-water recharge to Quabbin reservoir, central Massachusetts. - Forest Ecology and Management 143: 115-129.

[10] Bosch, J. M., Hewlett, J. D. (1982): A review of catchment experiments to determine the effect of vegetation changes on water yield and evapotranspiration. - Journal of Hydrology 55: 3-23.

[11] Brechtel, H. M., Fuhrer, H. W. (1991): Water yield control in beech forest. A paired watershed study in the Krofdorf forest research area. $-20^{\text {th }}$ General Assembly of the International Union of Geodesy and Geophysics, Vienna, Austria 8: 477-84.

[12] Brown, A. E., Zhang, L., McMahon, T. A., Western, A. W., Vertessy, R. A. (2005): A review of paired catchment studies for determining changes in water yield resulting from alterations in vegetation. - Journal of hydrology 310(1-4): 28-61.

[13] Brown, A. E., Western, A. W., McMahon, T. A., Zhang, L. (2013): Impact of forest cover changes on annual streamflow and flow duration curves. - Journal of Hydrology 483: 39-50. https://doi.org/10.1016/j.jhydrol.2012.12.031.

[14] Burton, T. A. (1997): Effects of basin-scale timber harvest on water yield and peak streamflow 1. - JAWRA Journal of the American Water Resources Association 33: 1187-1196. https://doi.org/10.1111/j.1752-1688.1997.tb03545.x.

[15] Calder, I. R. (1999): The Blue Revolution: Land Use and Integrated Water Resources Management. - Earthscan, London.

[16] Calder, I. R., Reid, I., Nisbet, T. R., Green, J. C. (2003): Impact of lowland forests in England on water resources: application of the hydrological land use change (HYLUC) model. - Journal of Water Resources Research 39(11).

[17] Cannell, M. G. R. (1999): Environmental impacts of forest monocultures: water use, acidification, wildlife conservation, and carbon storage. - New Forests 17: 239-262.

[18] Catovsky, S., Holbrook, N. M., Bazzaz, F. A. (2002): Coupling whole-tree transpiration and canopy photosynthesis in coniferous and broad-leaved tree species. - Canadian Journal of Forest Research 32: 295-309.

[19] Cheng, J. D. (1989): Streamflow changes after clear-cut logging of a pine beetle-infested watershed in southern British Columbia, Canada. - Water Resources Research 25: 449-56.

[20] Cornish, P. M. (1993): The effects of logging and forest regeneration on water yields in a moist eucalypt forest in New South Wales, Australia. - Journal of Hydrology 150: 301-322. https://doi.org/10.1016/0022-1694(93)90114-O.

[21] Cosandey, C., Andréassian, V., Martin, C., Didon-Lescot, J. F., Didon-Lescot, J. F., Lavabre, J., Folton, N., Mathys, N., Richard, D. (2005): The hydrological impact of the Mediterranean forest: a review of French research. - Journal of Hydrology 301: 235-49. 
[22] Costanza, R., d'Arge, R., de Groot, R., et al. (1997): The value of the world's ecosystem services and natural capital. - Nature 387: 253-260.

[23] David, J. S., Henriques, M. O., David, T. S., Tomé, J., Ledger, D. C. (1994): Clearcutting effects on streamflow in coppiced Eucalyptus globulus stands in Portugal. - Journal of Hydrology 162: 143-154. https://doi.org/10.1016/0022-1694(94)90008-6.

[24] Ellison, D., Futter, M. N., Bishop, K. (2012): On the forest cover-water yield debate: from demand to supply side thinking. - Global Change Biology 18: 806-820.

[25] Ellison, D., Morris, C. E., Locatelli, B., Sheil, D., Cohen, J., Murdiyarso, D., Gutierrez, V., Van Noordwijk, M., Creed, I. F., Pokorny, J., Gaveau, D. (2017): Trees, forests and water: cool insights for a hot world. - Global Environmental Change 43: 51-61.

[26] Fahey, B. (1994): The effect of plantation forestry on water yield in New Zealand. New Zealand Forestry 39: 18-23.

[27] Fahey, B., Jackson, R. (1997): Hydrological impacts of converting native forests and grasslands to pine plantations, South Island, New Zealand. - Agricultural and Forest Meteorology 84: 69-82.

[28] Farley, K. A., Jobbagy, E. G., Jackson, R. B. (2005): Effects of afforestation on water yield: a global synthesis with implications for policy. - Global Change Biology 11: 1565-1576. DOI: 10.1111/j.1365-2486.2005. 01011.x.

[29] Farooqi, T. J. A., Hayat, U., Roman, M., Abbas H., Hussain S. (2020a): Comparative study determining the impacts of broadleaved and needle leaved forest harvesting on hydrology and water yield: state of knowledge and research outlook. - International Journal of Biosciences 16(2): 231-240. http://dx.doi.org/10.12692/ijb/16.2.231-240.

[30] Farooqi, T.J.A., Li, X., Yu, Z., Liu, S. and Sun, O.J. (2020b): Reconciliation of research on forest carbon sequestration and water conservation. -Journal of Forestry Research, pp.1-8. https://doi.org/10.1007/s11676-020-01138-2.

[31] Fritsch, J. M. (1990): Les effets du de'frichement de la fore`t amazonienne et de la mise en culture sur l'hydrologie des petits bassins versants. - PhD Thesis. Universite' des Sciences et Techniques du Languedoc, Montpellier.

[32] Gower, S., Krankina, O., Olson, R., Apps, M., Linder, S., Wang, C. (2001): Net primary production and carbon allocation patterns of boreal forest ecosystems. Ecological Applications 11: 1395-1411.

[33] Harding, R. J., Hall, R. L., Neal, C. (1992): Hydrological Impacts of Broadleaf Woodlands: Implications for Water Use and Water Quality. - National Rivers Authority Report 115/03/ST. HSMO, London.

[34] Hornbeck, J. W., Adams, M. B., Corbett, E. S., Verry, E. S., Lynch, J. A. (1993): Longterm impacts of forest treatments on water yield: a summary for Northeastern USA. Journal of Hydrology 150: 323-344. DOI: 10.1016/ 0022-1694(93)90115-P.

[35] Hornbeck, J. W., Martin, C. W., Eagar, C. (1997): Summary of water yield experiments at Hubbard Brook experimental forest, New Hampshire. - Canadian Journal of Forest Research 27(12): 2043-2052.

[36] Houghton, R. A., House, J. I., Pongratz, J., Van Der Werf, G. R., DeFries, R. S., Hansen, M. C., Le Quéré, C., Ramankutty, N. (2012): Carbon emissions from land use and land-cover change. - Biogeosciences 9: 5125-5142.

[37] Hubbart, J. A., Link, T. E., Gravelle, J. A., Elliot, W. J. (2007): Timber harvest impacts on water yield in the continental/maritime hydroclimatic region of the United States. Forest Science 53: 169-180.

[38] Huber, A., Iroumé, A. (2001): Variability of annual rainfall partitioning for different sites and forest covers in Chile. - Journal of Hydrology. 248: 78-92.

[39] Iroume, A., Huber, A. (2002): Comparison of interception losses in a broadleaved native forest and a' Pseudotsuga menziesii plantation in the Andes Mountains of southern Chile. - Hydrological Processes 16: 2347-2361.

[40] Jackson, R. B., Jobbágy, E. G., Avissar, R., Roy, S. B., Barrett, D. J., Cook, C. W., Farley, K. A., Le Maitre, D. C., McCarl, B. A., Murray, B. C. (2005): Trading water for 
carbon with biological carbon sequestration. - Science 310: 1944-1947. DOI: 10.1126/science. 1119282 .

[41] Jones, H. S., Beets, P. N., Kimberley, M. O., Garrett, L. G. (2011): Harvest residue management and fertilisation effects on soil carbon and nitrogen in a 15-year old Pinus radiate plantation forest. - Forest Ecology Management 262: 339-347. https://doi.org/10.1016/j.foreco.2011.03.040.

[42] Jones, J. A., Post, D. A. (2004): Seasonal and successional streamflow response to forest cutting and regrowth in the northwest and eastern United States. - Water Resources Research 40(5).

[43] Kabeya, N., Chappell, N. A., Tych, W., Shimizu, A., Asano, S., Hagino, H. (2016): Quantification of the effect of forest harvesting versus climate on streamflow cycles and trends in an evergreen broadleaf catchment. - Hydrological Sciences Journal 61: 16-27.

[44] Kelliher, F. M., Leuning, R., Raupach, M. R., Schulze, E. D. (1995): Maximum conductances for evaporation from global vegetation types. - Agricultural and Forest Meteorology 73: 1-16.

[45] Keppeler, E. T., Ziemer, R. R. (1990): Logging effects on streamflow: water yield and summer low flows at Caspar Creek in north-western California. - Water Resources Research 26: 1669-1679.

[46] Khan, O.J., Muhammad, B., Ali T, Ullah S., Ali M. (2019): Underlying factors of deforestation and its effects in Sanger Valley District Swat. - Journal of Biodiversity and Environmental Sciences 15(5):14-28.

[47] Komatsu, H., Shinohara, Y., Kume, T., Otsuki, K. (2008): Relationship between annual rainfall and interception ratio for forests across Japan. - Forest Ecology and Management 256: 1189-1197. DOI: 10.1016/j. foreco.2008.06.036.

[48] Komatsu, H., Kume, T., Otsuki, K. (2009): Changes in low flow with the conversion of a coniferous plantation to a broad-leaved forest in a summer precipitation region, Japan. - Ecohydrology 2(2): 164-172.

[49] Komatsu, H., Kume, T., Otsuki, K. (2011): Increasing annual runoff-broadleaf or coniferous forests? - Hydrol Process 25: 302-318. https://doi.org/10.1002/hyp.7898.

[50] Krankina, O. N., Dixon, R. K., Kirilenko, A. P., Kobak, K. I. (1997): Global climate change adaptation: examples from Russian boreal forests. - Climatic Change 36: 197216.

[51] Lane, P. N. J., Mackay, S. M. (2001): Streamflow response of mixed species eucalypt forests to patch cutting and thinning treatments. - Forest Ecology and Management 143: 131-142. https://doi.org/10.1016/S0378-1127(00)00512-0.

[52] Law, B. E., Falge, E., Gu, L. V., Baldocchi, D. D., Bakwin, P., Berbigier, P., Davis, K., Dolman, A. J., Falk, M., Fuentes, J. D., Goldstein, A.(2002): Environmental controls over carbon dioxide and water vapor exchange of terrestrial vegetation. - Agricultural and Forest Meteorology 113: 97-120.

[53] Li, X., Farooqi, T. J. A., Jiang, C., Liu, S., Sun, O. J. (2019): Spatiotemporal variations in productivity and water use efficiency across a temperate forest landscape of Northeast China. - Forest Ecosystems 6: 22. https://doi.org/10.1186/s40663-019-0179-x.

[54] Masiero, M., Pettenella, D., Boscolo, M., Kanti Barua, S., Animon, I., Matta, R. (2019): Valuing Forest Ecosystem Services: A Training Manual for Planners and Project Developers. - Food and Agriculture Organization of the United Nations, Rome.

[55] Meinzer, F. C., Grantz, D. A. (1991): Coordination of stomatal, hydraulic, and canopy boundary properties: do stomata balance conductance by measuring transpiration? Physiologia Plantarum 83: 324-329.

[56] Muhammad, B., Ilahi, T., Ullah, S., Wu, X., Siddique, M. A., Khan, M. A., Badshah, M. T., Jia, Z (2020) Litter decomposition and soil nutrients prince rupprecht's (larix principis-rupprechtii) plantations area in Saihanba, Northern China. - Applied Ecology and Environmental Research (In press) 
[57] Muzylo, A., Llorens, P., Valente, F., Keizer, J. J., Domingo, F., Gash, J. H. C. (2009): A review of rainfall interception modelling. - Journal of Hydrology 370: 191-206. DOI: 10.1016/j.jhydrol.2009.02.058.

[58] Nasi, R., Wunder, S., Campos, J. J. (2002): Forest ecosystem services: can they pay our way out of deforestation? - A Discussion Paper Prepared for the GEF Forestry Roundtable to be Held in Conjunction with the UNFF II, Costa Rica on March 11, 2002.

[59] Oren, R., Zimmerman, R., Terborgh, J. (1996): Transpiration in upper Amazonian floodplain and upland forests in response to drought breaking rains. - Ecology 77: 968973.

[60] Pearce, A. J., Rowe, L. K., O’Loughlin, C. L. (1980): Effects of clearfelling and slashburning on water yield and storm hydrographs in evergreen mixed forests, western New Zealand. - Proceedings on the Influence of Man on the Hydrological Regime with Special Reference to Representative and Experimental Basins, Helsinki, June 1980. IAHS-AISH Publication No 130, pp. 119-127.

[61] Pike, R., Scherer, R. (2003): Overview of the potential effects of forest management on low flows in snowmelt-dominated hydrologic regimes. - Journal of Ecosystems and Management 3: 3.

[62] Popkin, G. (2019): How much can forests fight climate change? - Nature. DOI: 10.1038/d41586-019-00122-z.

[63] Raupach, M. R. (1995): Vegetation-atmosphere interaction and surface conductance at leaf, canopy and regional scales. - Agricultural and Forest Meteorology 73: 151-179.

[64] Roberts, J. (1983): Forest transpiration: a conservative hydrological process? - Journal of Hydrology 66: 133 - 141.

[65] Roberts, J., Rosier, P. (2005): The impact of broadleaved woodland on water resources in lowland UK: III. The results from Black Wood and Bridgets Farm compared with those from other woodland and grassland sites. - Hydrology and Earth System Sciences 9: 614-620.

[66] Rowe, L. K., Jackson, R., Fahey, B. (2002): Land use and water resources: hydrological effects of different vegetation covers. - SMF2167, Report. 5.

[67] Ruddell, S., Sampson, R., Smith, M., Giffen, R., Cathcart, J., Hagan, J., Sosland, D., Godbee, J., Heissenbuttel, J., Lovett, S., Helms, J. (2007): The role for sustainably managed forests in climate change mitigation. - Journal of Forestry 105: 314-319.

[68] Ruprecht, J. K., Stoneman, G. L. (1993): Water yield issues in the jarrah forest of south-western Australia. - Journal of Hydrology 150: 369-391.

[69] Sahin, V., Hall, M. J. (1996): The effects of afforestation and deforestation on water yields. - Journal of Hydrology 178: 293-309.

[70] Siddique, M.A., Dongyun, L., Li, P., Rasool, U., Khan, T.U., Farooqi, T.J.A., Wang, L., Fan, B. and Rasool, M.A. (2020): Assessment and simulation of land use and land cover change impacts on the land surface temperature of Chaoyang District in Beijing, China. - PeerJ 8:p.e9115.

[71] Scott, D. F., Scott, D. F. (2000): A Re-analysis of the South African Catchment Afforestation Experimental Data. - Water Research Commission, Pretoria.

[72] Smith, P. J. T. (1987): Variation of water yield from catchments under grass and exotic forest, east Otago. - Journal of Hydrology 26: 175-184.

[73] Stednick, J. D. (1996): Monitoring the effects of timber water yield harvest on annual. Journal of Hydrology 176: 79-95.

[74] Su, H., Li, Y., Liu, W., Xu, H., Su, H., Li, Y., Liu, W., Xu, H., Sun, O. J. (2014): Changes in water use with growth in Ulmus pumila in semiarid sandy land of northern China. - Trees 28: 41-52.

[75] Sun, G., Zhou, G. Y., Zhang, Z. Q., Wei, X., McNulty, S. G., Vose, J. M. (2006): Potential water yield reduction due to forestation across China. - Journal of Hydrology 328: 548-558. 
[76] Sun, G., Zuo, C. Q., Liu, S. Y., Liu, M., McNulty, S. G., Vose, J. M. (2008): Watershed evapotranspiration increased due to changes in vegetation composition and structure under a subtropical climate. - J Am Water Resource Association 44: 1164-1175.

[77] Swank, W. T., Helvey, J. D. (1970): Reduction of streamflow increases following regrowth of clearcut hardwood forests. - Symposium on the Results of Research on Representative and Experimental Basins, December 1970, UNESCO-IASH, Leuven, pp. 346-360.

[78] Swank, W. T., Douglass, J. E. (1974): Streamflow greatly reduced by converting deciduous hardwood stands to pine. - Science 185: 857-859.

[79] Swank, W. T., Vose, J. M., Elliot, K. J. (2001): Long-term hydrologic and water quality responses following commercial clearcutting of mixed hardwoods on a southern Appalachian catchment. - Forest Ecology and Management 143: 163-178.

[80] Swift Jr, L. W., Swank, W. T. (1981): Long term responses of streamflow following clearcutting and regrowth/Réactions à long terme du débit des cours d'eau après coupe et repeuplement. - Hydrological Sciences Journal 26: 245-56.

[81] Tan, Z. H., Zhang, Y. P., Deng, X. B., Song, Q. H., Liu, W. J., Deng, Y., Tang, J. W., Liao, Z. Y., Zhao, J. F., Song, L., Yang, L. Y. (2015): Interannual and seasonal variability of water use efficiency in a tropical rainforest: results from a 9-year eddy flux time series. - Journal of Geophysical Research: Atmospheres 120: 464-479.

[82] Troendle, C. A., Wilcox, M. S., Bevenger, G. S., Porth, L. S. (2001): The Coon Creek water yield augmentation project: implementation of timber harvesting technology to increase streamflow. - Forest Ecology and Management 143: 179-187.

[83] Ullah, F., Ullah, S., Ashraf, M, I., Ali T., Abbas H., Muhammad, B., Badshah, M, T. (2019a): REDD+impacts on the livelihood of the community and their involvement in the policymaking process. - Journal of Biodiversity and Environmental Sciences 15(1): 102110.

[84] Ullah S., Muhammad B., Amin R., Abbas H., Muneer, M. (2019b): Sensitivity of arbuscular mycorrhizal fungi in old-growth forests: direct effect on growth and soil carbon storage. - Applied Ecology and Environmental Research 17: 13749-13758.

[85] Van der Ent, R. J., Savenije, H. H., Schaefli, B., Steele-Dunne, S. C. (2010): Origin and fate of atmospheric moisture over continents. - Water Resources Research 46(9).

[86] van Dijk, A. I. J. M., Keenan, R. J. (2007): Planted forests and water in perspective. Forest Ecology and Management 251: 1-9. https://doi.org/10.1016/j.foreco.2007.06.010.

[87] Van Wijk, M. T., Dekker, S. C., Bouten, W., Kohsiek, W., Mohren, G. M. J. (2001): Simulation of carbon and water budgets of a Douglas-fir forest. - Forest Ecology and Management 145: 229-241.

[88] Vertessy, R. A., Watson, F. G. R., O’Sullivan, S. K. (2001): Factors determining relations between stand age and catchment water balance in mountain ash forests. Forest Ecology and Management 143: 13-26.

[89] Wang, J., Zhang, D., Farooqi. T. J. A., Ma, L., Deng, Y., Jia, Z. (2017): The olive (Olea europaea L.) industry in China: its status, opportunities and challenges. - Agroforestry Systems 9: 395-417. DOI: 10.1007/s10457-017-0129-y.

[90] Webb, A. A. (2009): Streamflow response to Pinus plantation harvesting: Canobolas State forest, southeastern Australia. - Hydrological Processes 23: 1679-89.

[91] Wilson, K. B., Hanson, P. J., Mulholland, P. J., Wilson, K. B., Hanson, P. J., Mulholland, P. J., Baldocchi, D. D., Wullschleger, S. D. (2001): A comparison of methods for determining forest evapotranspiration and its components: sap-flow, soil water budget, eddy covariance and catchment water balance. - Agricultural and Forest Meteorology 106: 153-168. 
[92] Zhang, L., Dawes, W. R., Walker, G. R. (2001): Response of mean annual evapotranspiration to vegetation changes at catchment scale. - Water Resources Research 37: 701-708.

[93] Zhang, L., Zhao, F. F., Brown, A. E. (2012): Predicting effects of plantation expansion on streamflow regime for catchments in Australia. - Hydrology and Earth System Sciences 16: 2109-2121.

[94] Zhang, M., Liu, N., Harper, R., Li, Q., Liu, K., Wei, X., Ning, D., Hou, Y., Liu, S. (2017): A global review on hydrological responses to forest change across multiple spatial scales: importance of scale, climate, forest type and hydrological regime. Journal of Hydrology 546: 44-59. DOI: 10.1016/j.jhydrol.2016.12.040.

\section{APPENDIX}

Appendix 1. Normality test results of Shaprio-wilk reject normality at $P<0.05$

\begin{tabular}{c|c|c|c|c}
\hline H.I. & DF & Statistics & P-value & Decision at level (5\%) \\
\hline $25 \% \mathrm{NL}$ & 167 & 0.87663 & $1.6514 \mathrm{E}-10$ & Reject normality \\
$25 \% \mathrm{BL}$ & 133 & 0.6918 & $2.38698 \mathrm{E}-15$ & Reject normality \\
$50 \% \mathrm{NL}$ & 167 & 0.92063 & $6.51603 \mathrm{E}-8$ & Reject normality \\
$50 \% \mathrm{BL}$ & 133 & 0.83991 & $1.02842 \mathrm{E}-10$ & Reject normality \\
$75 \% \mathrm{NL}$ & 167 & 0.9465 & $5.95852 \mathrm{E}-6$ & Reject normality \\
$75 \% \mathrm{BL}$ & 133 & 0.90299 & $8.54516 \mathrm{E}-8$ & Reject normality \\
$100 \% \mathrm{NL}$ & 167 & 0.96282 & $1.93127 \mathrm{E}-4$ & Reject normality \\
$100 \% \mathrm{BL}$ & 133 & 0.92935 & $3.17434 \mathrm{E}-6$ & Reject normality \\
\hline
\end{tabular}

H.I.: harvesting intensity $(\%)$

Appendix 2. QQ plot representing the distribution of change in water yield (\%) after 25, 50, 75 and $100 \%$ of harvesting intensities of the dataset. The scores are negatively skewed (fewer scores at the low end)
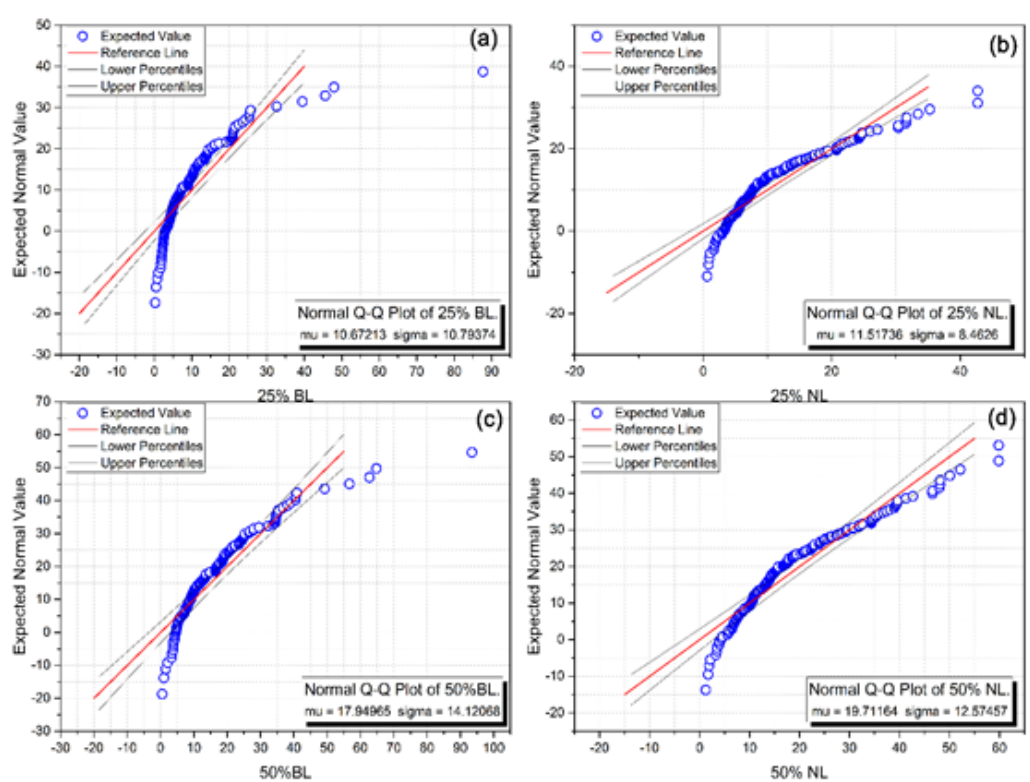

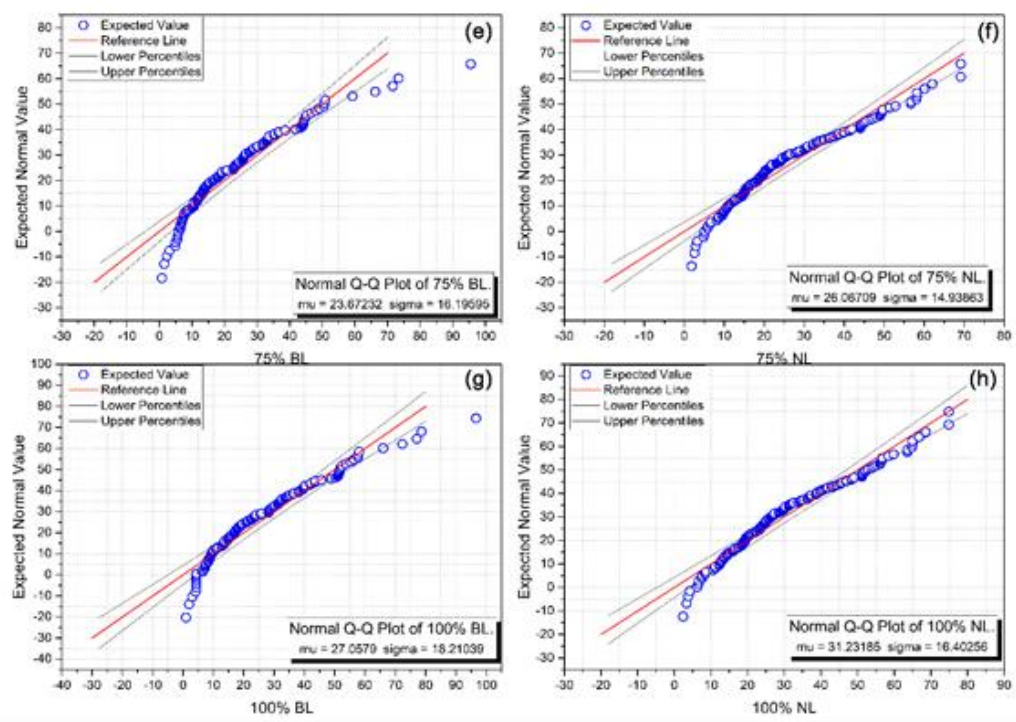

Appendix 3. Kruskal-Wallis ANOVA, representing the descriptive statistic results of different harvesting intensities of broadleaved $(B L)$ and needle leaved $(N L)$ forests on change in water yield $(\%)$

\begin{tabular}{c|c|c|c|c|c|c}
\hline H.I. & N & Min & Q1 & Median & Q3 & Max \\
\hline "25\%NL" & 167 & 0.61635 & 5.71968 & 9.04704 & 15.52163 & 42.71476 \\
"25\%BL" & 133 & 0.25043 & 4.24867 & 7.88758 & 13.50434 & 87.69458 \\
"50\%NL" & 167 & 1.22515 & 10.82046 & 16.59292 & 26.87225 & 59.86033 \\
"50\%BL" & 133 & 0.4996 & 8.15101 & 14.62185 & 23.79504 & 93.44391 \\
"75\%NL" & 167 & 1.82653 & 15.39764 & 22.98264 & 35.53398 & 69.10673 \\
"75\%BL" & 133 & 0.74753 & 11.74769 & 20.43853 & 31.89731 & 95.53162 \\
"100\%NL" & 167 & 2.42063 & 19.5279 & 28.463 & 42.36111 & 42.36111 \\
"100\%BL" & 133 & 0.99423 & 13.54604 & 22.96223 & 38.15074 & 96.61086 \\
\hline
\end{tabular}

H.I: harvesting intensity $(\%), \mathrm{P}<0.0001$, Chi-square $=295.027$

Appendix 4. Wilcoxon signed ranks test

\begin{tabular}{c|c|c|c}
\hline Paired sample & W & Z & P-value \\
\hline "25\%BL"-"25\%NL" & 5869 & 3.17332 & 0.00151 \\
"50\%BL"-"50\%NL" & 5903 & 3.24968 & 0.00116 \\
"75\%BL"-"75\%NL" & 5927 & 3.30358 & $9.54597 \mathrm{E}-4$ \\
"100\%BL"-"100\%NL" & 6206 & 3.93016 & $8.48907 \mathrm{E}-5$ \\
\hline
\end{tabular}

$* \mathrm{P}<0.05$

Appendix 5. Data set used in the synthesis

\begin{tabular}{c|c|c|c|c|c|c|c|c}
\hline \multicolumn{10}{c}{ Broadleaved forest } \\
\hline Source & Catchment & Country & $\begin{array}{c}\text { Elv. } \\
(\mathbf{m})\end{array}$ & Soil type & $\begin{array}{c}\text { Area } \\
(\mathbf{h a})\end{array}$ & $\begin{array}{c}\text { MAP } \\
(\mathbf{m m})\end{array}$ & $\begin{array}{c}\text { MAS } \\
(\mathbf{m m})\end{array}$ & DF (\%) \\
\hline $\begin{array}{c}\text { Bosch and Hewlett } \\
(1982)\end{array}$ & Coweeta 13 & USA & 810 & Sandy clay loam & 16 & 1900 & 889 & 100 \\
\hline
\end{tabular}




\begin{tabular}{|c|c|c|c|c|c|c|c|c|}
\hline $\begin{array}{c}\text { Bosch and Hewlett } \\
\text { (1982) }\end{array}$ & Coweeta 19 & USA & 960 & Sandy clay loam & 28 & 2001 & 1222 & 22 \\
\hline $\begin{array}{c}\text { Bosch and Hewlett } \\
\text { (1982) }\end{array}$ & Coweeta 1 & USA & 840 & Sandy clay loam & 16 & 1725 & 739 & 100 \\
\hline $\begin{array}{c}\text { Bosch and Hewlett } \\
\text { (1982) }\end{array}$ & Coweeta 28 & USA & 1200 & Sandy clay loam & 144 & 2270 & 1532 & 65 \\
\hline $\begin{array}{c}\text { Bosch and Hewlett } \\
\text { (1982) }\end{array}$ & Coweeta 17 & USA & 885 & Sandy clay loam & 14 & 1895 & 775 & 100 \\
\hline $\begin{array}{c}\text { Bosch and Hewlett } \\
\text { (1982) }\end{array}$ & Coweeta 22 & USA & 1035 & Sandy clay loam & 34 & 2068 & 1275 & 50 \\
\hline $\begin{array}{c}\text { Bosch and Hewlett } \\
\text { (1982) }\end{array}$ & Coweeta 3 & USA & 825 & Sandy clay loam & 9 & 1814 & 607 & 100 \\
\hline $\begin{array}{c}\text { Bosch and Hewlett } \\
\text { (1982) }\end{array}$ & Coweeta 10 & USA & 975 & Sandy clay loam & 86 & 1854 & 1072 & 30 \\
\hline $\begin{array}{c}\text { Bosch and Hewlett } \\
\text { (1982) }\end{array}$ & Coweeta 41 & USA & 1065 & Sandy clay loam & 29 & 2029 & 1285 & 53 \\
\hline $\begin{array}{c}\text { Bosch and Hewlett } \\
\text { (1982) }\end{array}$ & Coweeta 6 & USA & 793 & Sandy clay loam & 9 & 1854 & 838 & 80 \\
\hline $\begin{array}{c}\text { Bosch and Hewlett } \\
(1982)\end{array}$ & Kericho Sambret & Kenya & 2200 & Deep friable clay & 688 & 1905 & 416 & 34 \\
\hline $\begin{array}{c}\text { Bosch and Hewlett } \\
\text { (1982) }\end{array}$ & Kimakia A & Kenya & 2440 & Deep friable clay & 35 & 2014 & 568 & 100 \\
\hline $\begin{array}{c}\text { Bosch and Hewlett } \\
\text { (1982) }\end{array}$ & Fernow 1 & USA & 755 & Stony silt loam & 30 & 1524 & 584 & 85 \\
\hline $\begin{array}{c}\text { Bosch and Hewlett } \\
\text { (1982) }\end{array}$ & Fernow 2 & USA & 780 & Stony silt loam & 15 & 1500 & 660 & 36 \\
\hline $\begin{array}{c}\text { Bosch and Hewlett } \\
\text { (1982) }\end{array}$ & Fernow 5 & USA & 780 & Stony silt loam & 36 & 1473 & 732 & 20 \\
\hline $\begin{array}{c}\text { Bosch and Hewlett } \\
\text { (1982) }\end{array}$ & Fernow 3 & USA & 805 & Stony silt loam & 34 & 1500 & 607 & 13 \\
\hline $\begin{array}{c}\text { Bosch and Hewlett } \\
\text { (1982) }\end{array}$ & Fernow 7 & USA & 800 & Stony silt loam & 24 & 1469 & 788 & 50 \\
\hline $\begin{array}{c}\text { Bosch and Hewlett } \\
\text { (1982) }\end{array}$ & Fernow 6 & USA & & Stony silt loam & 22 & 1440 & 493 & 50 \\
\hline $\begin{array}{c}\text { Bosch and Hewlett } \\
\text { (1982) }\end{array}$ & Leading Ridge WS2 & USA & 385 & Silt loam & 43 & 1004 & 321 & 20 \\
\hline $\begin{array}{c}\text { Bosch and Hewlett } \\
\text { (1982) }\end{array}$ & Placer County Ws C & USA & 168 & Clay loam & 5 & 635 & 145 & 99 \\
\hline $\begin{array}{c}\text { Bosch and Hewlett } \\
(1982)\end{array}$ & Maimai M7 & New Zealand & 300 & Stoney silt loam & 4 & 2600 & 1500 & 100 \\
\hline $\begin{array}{c}\text { Bosch and Hewlett } \\
\text { (1982) }\end{array}$ & Maimai M9 & New Zealand & 310 & Stoney silt loam & 8 & 2600 & 1500 & 75 \\
\hline Andréassian (2004) & Leading Ridge 2 & \multicolumn{2}{|l|}{ USA } & & 43 & 1060 & 440 & 86 \\
\hline Andréassian (2004) & Dantzoud & \multicolumn{2}{|c|}{ Armenia } & & 14100 & 680 & 413 & 11 \\
\hline Andréassian (2004) & Girants & \multicolumn{2}{|c|}{ Armenia } & & 12200 & 700 & 224 & 7 \\
\hline Bent (2001) & Dickey brook & USA & 308 & & 308 & 1250 & 430 & 32 \\
\hline $\begin{array}{l}\text { Brechtel and } \\
\text { Fuhrer(1991) }\end{array}$ & Krofdorf A1 & Germany & 336 & Rocky & 9.3 & 650 & 300 & 100 \\
\hline $\begin{array}{c}\text { Fahey and Jackson } \\
\text { (1997) }\end{array}$ & Big bush DC1 & \multicolumn{2}{|c|}{ New Zealand } & & 8.6 & 1530 & 610 & 83 \\
\hline $\begin{array}{c}\text { Fahey and Jackson } \\
(1997)\end{array}$ & Big bush DC4 & \multicolumn{2}{|c|}{ New Zealand } & & 20.2 & 1530 & 670 & 94 \\
\hline Fritsch (1992) & Hakhoum & \multicolumn{2}{|c|}{ Armenia } & & \#\#\#\# & 675 & 268 & 7 \\
\hline Sahin and Hall (1996) & WS2L.R. & USA & 360 & Silt loam & 43 & 1060 & 440 & 43 \\
\hline Sahin and Hall (1996) & WS4H.B & USA & 606 & Sandy loam & 36 & 1340 & 860 & 33 \\
\hline Stednick (1996) & Coweeta 7 & USA & 900 & Loam & 59 & 1825 & 1140 & 100 \\
\hline Stednick (1996) & Fernow 3 & USA & 805 & Silt loam & 34 & 1500 & 610 & 91 \\
\hline Stednick (1996) & Ouachita, OKWS10 & USA & & Loam & 5.7 & 1317 & 1652 & 50 \\
\hline Stednick (1996) & Ouachita, OKWS12 & USA & & Loam & 5.9 & 1317 & 1652 & 100 \\
\hline Stednick (1996) & Ouachita, OKWS14 & USA & & Loam & 4.3 & 1317 & 1652 & 50 \\
\hline
\end{tabular}




\begin{tabular}{|c|c|c|c|c|c|c|c|c|}
\hline Stednick (1996) & Ouachita, OKWS15 & USA & & Loam & 5.1 & 1317 & 1652 & 100 \\
\hline Stednick (1996) & Ouachita, OKWS17 & USA & & Loam & 4.2 & 1317 & 1652 & 50 \\
\hline Stednick (1996) & Ouachita, OKWS18 & USA & & & 4.1 & 1317 & 1652 & 100 \\
\hline Anderson et al. (1976) & WN-Carolina 1 & USA & & & 15 & 1828 & 787 & 100 \\
\hline Anderson et al. (1976) & WN-Carolina 3 & USA & & & 9 & 1803 & 610 & 100 \\
\hline Anderson et al. (1976) & WN-Carolina 5 & USA & & & 28 & 2006 & 1219 & 22 \\
\hline Anderson et al. (1976) & WN-Carolina 6 & USA & & & 83 & 1854 & 1067 & 30 \\
\hline Anderson et al. (1976) & WN-Carolina 7 & USA & & & 28 & 2032 & 1295 & 35 \\
\hline Anderson et al. (1976) & NW-Virginia 1 & USA & & & 22 & 1448 & 762 & 100 \\
\hline Anderson et al. (1976) & NW-Virginia 3 & USA & & & 23 & 1447 & 762 & 50 \\
\hline Anderson et al. (1976) & NW-Virginia 5 & USA & & & 33.4 & 1498 & 635 & 14 \\
\hline $\begin{array}{c}\text { Hornbeck et al. (1993), } \\
\text { Kabeya et al. (2015) }\end{array}$ & Pennsylvani LR-WS3 & USA & 340 & & 104 & 1060 & 440 & 43 \\
\hline $\begin{array}{l}\text { Hornbeck et al. (1993), } \\
\text { Kabeya et al. (2015) }\end{array}$ & Pennsylvani LR-WS2 & USA & 360 & & 43 & 1060 & 440 & 24 \\
\hline Swift and Swank (1981) & Coweeta 13 & USA & 810 & Clay loam & 16 & 1900 & 889 & 100 \\
\hline Swift and Swank (1981) & Coweeta 37 & USA & 1300 & Sandy clay loam & 44 & 2220 & 1604 & 100 \\
\hline Swift and Swank (1981) & Coweeta 28 & USA & 1200 & & 144 & 2320 & 1534 & 65 \\
\hline Andréassian (2004) & Karuah/Kokata & \multicolumn{2}{|c|}{ Australia } & & 97.4 & 1565 & 531 & 29 \\
\hline Andréassian (2004) & Karuah/Coachwood & \multicolumn{2}{|c|}{ Australia } & & 37.5 & 1447 & 362 & 61 \\
\hline Andréassian (2004) & Karuah/Corkwood & \multicolumn{2}{|c|}{ Australia } & & 41.1 & 1636 & 505 & 40 \\
\hline Andréassian (2004) & Karuah/Jackwood & \multicolumn{2}{|c|}{ Australia } & & 12.5 & 1373 & 311 & 79 \\
\hline Andréassian (2004) & Karuah/Bollygum & \multicolumn{2}{|c|}{ Australia } & & 15.1 & 1518 & 505 & 32 \\
\hline Andréassian (2004) & Monda 1 & \multicolumn{2}{|c|}{ Australia } & $\begin{array}{c}\text { Rocky } \\
\text { Krasnozems }\end{array}$ & 6.3 & 1876 & 702 & 75 \\
\hline Andréassian (2004) & Monda 2 & \multicolumn{2}{|c|}{ Australia } & $\begin{array}{c}\text { Rocky } \\
\text { Krasnozems }\end{array}$ & 4 & 1813 & 550 & 75 \\
\hline Andréassian (2004) & Monda 3 & \multicolumn{2}{|c|}{ Australia } & $\begin{array}{c}\text { Rocky } \\
\text { Krasnozems }\end{array}$ & 7.3 & 1763 & 632 & 75 \\
\hline Andréassian (2004) & Myrtle 2 & \multicolumn{2}{|c|}{ Australia } & $\begin{array}{c}\text { Rocky } \\
\text { Krasnozems }\end{array}$ & 30.5 & 1590 & 852 & 74 \\
\hline Andréassian (2004) & Picaninny & \multicolumn{2}{|c|}{ Australia } & & 53 & 1180 & 332 & 78 \\
\hline Andréassian (2004) & Black Spur 1 & \multicolumn{2}{|c|}{ Australia } & $\begin{array}{c}\text { Rocky } \\
\text { Krasnozems }\end{array}$ & 17 & 1652 & 504 & 60 \\
\hline Andréassian (2004) & Black Spur 3 & \multicolumn{2}{|c|}{ Australia } & $\begin{array}{c}\text { Rocky } \\
\text { Krasnozems }\end{array}$ & 7.7 & 1612 & 530 & 60 \\
\hline Andréassian (2004) & Wicksend & \multicolumn{2}{|c|}{ Australia } & & 68 & 1200 & 440 & 22 \\
\hline Andréassian (2004) & Wilbob & \multicolumn{2}{|c|}{ Australia } & & 86 & 1200 & 392 & 12 \\
\hline Andréassian (2004) & Clem creek & \multicolumn{2}{|c|}{ Australia } & Rocky clay loam & 46.4 & 1445 & 190 & 95 \\
\hline Andréassian (2004) & Yarragil 4L & \multicolumn{2}{|c|}{ Australia } & & 126 & 1120 & 4.3 & 66 \\
\hline Sahin and Hall (1996) & Hansen & \multicolumn{2}{|c|}{ Australia } & Gravel & 80 & 1200 & 232 & 75 \\
\hline $\begin{array}{c}\text { Komatsu et al. (2011), } \\
\text { Pearce et al. (1980) }\end{array}$ & Maimai M7 & \multicolumn{2}{|c|}{ New Zealand } & & & 2600 & 1550 & 100 \\
\hline Pearce et al. (1980) & Maimai M9 & \multicolumn{2}{|c|}{ New Zealand } & & & 2600 & 1550 & 75 \\
\hline Stednick (1996) & Fernow 3 & USA & 805 & Silt loam & 34 & 1500 & 610 & 13 \\
\hline Stednick (1996) & Fernow 5 & USA & 760 & Silt loam & 36 & 1470 & 760 & 20 \\
\hline Stednick (1996) & Fernow 6 & USA & & Silt loam & 22 & 1440 & 490 & 50 \\
\hline Stednick (1996) & Fernow 7 & USA & 800 & Silt loam & 24 & 1470 & 790 & 50 \\
\hline Stednick (1996) & Leading Ridge PA2 & USA & 358 & Silt loam & 43 & 1000 & 320 & 20 \\
\hline Stednick (1996) & Coweeta, NC7 & USA & 900 & Loam & 59 & 1825 & 1140 & 100 \\
\hline Stednick (1996) & Grant forest GA18 & USA & 165 & Sandy loam & 33 & 1220 & 470 & 100 \\
\hline Stednick (1996) & Ouachita, OKWS10 & USA & & Loam & 6 & 1317 & 1652 & 50 \\
\hline Stednick (1996) & Ouachita, OKWS12 & USA & & Loam & 6 & 1317 & 1652 & 100 \\
\hline Stednick (1996) & Ouachita, OKWS14 & USA & & Loam & 4 & 1317 & 1652 & 50 \\
\hline Stednick (1996) & Ouachita, OKWS15 & USA & & Loam & 4 & 1317 & 1652 & 100 \\
\hline Stednick (1996) & Ouachita, OKWS17 & USA & & Loam & 4 & 1317 & 1652 & 50 \\
\hline
\end{tabular}




\begin{tabular}{|c|c|c|c|c|c|c|c|c|}
\hline \multicolumn{9}{|c|}{ Needle-leaved forest } \\
\hline Source & Catchment & Country & \begin{tabular}{|c|} 
Elev. \\
$(\mathrm{m})$
\end{tabular} & Soil type & $\begin{array}{c}\text { Area } \\
\text { (ha) }\end{array}$ & $\begin{array}{l}\text { MAP } \\
(\mathbf{m m})\end{array}$ & $\begin{array}{l}\text { MAS } \\
(\mathbf{m m})\end{array}$ & $\begin{array}{l}\text { DF } \\
(\%)\end{array}$ \\
\hline $\begin{array}{c}\text { Bosch and Hewlett } \\
\text { (1982) }\end{array}$ & Needle Branch & USA & 312 & Sand stone & 71 & 2483 & 1885 & 82 \\
\hline $\begin{array}{c}\text { Bosch and Hewlett } \\
\text { (1982) }\end{array}$ & Deer Creek & USA & 312 & Sand stone & 303 & 2474 & 1906 & 25 \\
\hline $\begin{array}{c}\text { Bosch and Hewlett } \\
\text { (1982) }\end{array}$ & H.J. Andrews 1 & USA & 700 & Clay loams & 96 & 2388 & 1376 & 100 \\
\hline $\begin{array}{c}\text { Bosch and Hewlett } \\
\text { (1982) }\end{array}$ & H.J. Andrews 3 & USA & 760 & Clay loams & 101 & 2388 & 1346 & 30 \\
\hline $\begin{array}{c}\text { Bosch and Hewlett } \\
\text { (1982) }\end{array}$ & H.J. Andrews 6 & USA & 900 & Volcaniclastics & 13 & 2150 & 1290 & 100 \\
\hline $\begin{array}{c}\text { Bosch and Hewlett } \\
\text { (1982) }\end{array}$ & H.J. Andrews 7 & USA & 900 & Volcaniclastics & 21 & 2150 & 1290 & 60 \\
\hline $\begin{array}{c}\text { Bosch and Hewlett } \\
\text { (1982) }\end{array}$ & H.J. Andrews 10 & USA & 500 & Volcaniclastics & 9 & 2330 & 1650 & 100 \\
\hline $\begin{array}{c}\text { Bosch and Hewlett } \\
\text { (1982) }\end{array}$ & Coyote Creek 1 & USA & 901 & Gravelly loam & 59 & 1230 & 627 & 50 \\
\hline $\begin{array}{c}\text { Bosch and Hewlett } \\
\text { (1982) }\end{array}$ & Coyote Creek 2 & USA & 901 & Gravelly loam & 68 & 1230 & 630 & 30 \\
\hline $\begin{array}{c}\text { Bosch and Hewlett } \\
\text { (1982) }\end{array}$ & Coyote Creek 3 & USA & & Gravelly loam & 50 & 1230 & 630 & 100 \\
\hline $\begin{array}{c}\text { Bosch and Hewlett } \\
\text { (1982) }\end{array}$ & Workman Creek, NF & USA & 2225 & Clay loam & 100 & 813 & 86 & 73 \\
\hline $\begin{array}{c}\text { Bosch and Hewlett } \\
\text { (1982) }\end{array}$ & Workman Creek, SF & USA & 2165 & Clay loam & 129 & 813 & 87 & 83 \\
\hline $\begin{array}{c}\text { Bosch and Hewlett } \\
\text { (1982) }\end{array}$ & Fool Creek & USA & 3200 & Permeable soil & 289 & 762 & 283 & 40 \\
\hline $\begin{array}{c}\text { Bosch and Hewlett } \\
\text { (1982) }\end{array}$ & Castle Creek & USA & 8207 & $\begin{array}{c}\text { Soil of igneous } \\
\text { origin }\end{array}$ & 364 & 639 & 71 & 17 \\
\hline $\begin{array}{c}\text { Bosch and Hewlett } \\
\text { (1982) }\end{array}$ & Beaver Creek 1 & USA & 1700 & Stony clay & 124 & 457 & 24 & 100 \\
\hline $\begin{array}{c}\text { Bosch and Hewlett } \\
\text { (1982) }\end{array}$ & Beaver Creek 3 & USA & 1600 & Stony clay & 146 & 457 & 18 & 83 \\
\hline $\begin{array}{c}\text { Bosch and Hewlett } \\
\text { (1982) }\end{array}$ & Wagon Wheel Gap & USA & 3110 & Rocky clay loam & 81 & 536 & 157 & 100 \\
\hline Burton (1997) & Brownie Creek & USA & 3082 & Sand stone & 2134 & 787 & 300 & 25 \\
\hline $\begin{array}{l}\text { Troendle et al. (2001), } \\
\text { Pike andScherer (2003) }\end{array}$ & Coon creek & USA & & & 1673 & 870 & 440 & 24 \\
\hline Cosandey (1990) & Latte & France & & & 20 & 1900 & 1278 & 100 \\
\hline Stednick (1996) & Workman Ce.AZ & USA & 2225 & Clay loam & 100 & 833 & 86 & 32 \\
\hline Stednick (1996) & N.Fork & USA & 2225 & Clay loam & 100 & 810 & 86 & 32 \\
\hline Stednick (1996) & Wagonwheel Gap.CO & USA & 3110 & Rocky clay loam & 81 & 544 & 157 & 100 \\
\hline Stednick (1996) & Chicken Creek M.OR1 & USA & 1523 & Ash & & 1355 & 472 & 50 \\
\hline Stednick (1996) & Chicken Creek M.OR2 & USA & 1523 & Ash & & 1355 & 460 & 50 \\
\hline Stednick (1996) & Chicken Creek M.OR3 & USA & 1523 & Ash & & 1355 & 372 & 50 \\
\hline Stednick (1996) & Fool Creek, CO & USA & 3200 & Granite & 289 & 760 & 280 & 40 \\
\hline Stednick (1996) & Fraser Forest, $\mathrm{CO}$ & USA & 3200 & Granite & 289 & 712 & 283 & 66 \\
\hline Stednick (1996) & Deadhorse Cr. CO & USA & 3120 & Granite & 270 & 762 & 500 & 36 \\
\hline Stednick (1996) & White Spar C & USA & 1420 & Quartz & 5 & 450 & 43 & 100 \\
\hline Stednick (1996) & Castle Creek, AZ & USA & & Igneous & 364 & 640 & 71 & 17 \\
\hline Stednick (1996) & Deer Creek, OR & USA & 312 & Marine sand stone & 303 & 2480 & 1910 & 25 \\
\hline Stednick (1996) & Needle Branch, OR & USA & 312 & Perm sand stone & 71 & 2480 & 1885 & 82 \\
\hline Stednick (1996) & Blue Mts1 & USA & 1523 & Ash & & 1355 & 472 & 50 \\
\hline Stednick (1996) & Blue Mts2 & USA & 1523 & Ash & & 1355 & 460 & 50 \\
\hline Stednick (1996) & Blue Mts3 & USA & 1523 & Ash & & 1355 & 372 & 50 \\
\hline Stednick (1996) & St Louis creek & USA & 3200 & Granite & 289 & 712 & 283 & 100 \\
\hline
\end{tabular}




\begin{tabular}{|c|c|c|c|c|c|c|c|c|}
\hline Stednick (1996) & Thomas creek, AZ & USA & 2600 & Loamy & 227 & 768 & 500 & 34 \\
\hline Stednick (1996) & Willow creek, AZ & USA & & Loam & & 749 & 512 & 62 \\
\hline Anderson (1976) & Western Oregon 1 & USA & & & 93 & 2362 & 1447 & 100 \\
\hline Anderson (1976) & Colorado 2 & USA & & & 281 & 762 & 279 & 40 \\
\hline Anderson (1976) & Arizona 2 & USA & & & 100 & 812 & 86 & 32 \\
\hline Cheng (1989) & Camp Creek, BC & USA & 1920 & Granite & 3390 & 600 & 140 & 30 \\
\hline Cheng (1989) & Hinton, Alberta & Canada & & & 1497 & 513 & 147 & 50 \\
\hline Cheng (1989) & Cabin Creek, Alberta & Canada & & & 212 & 840 & 310 & 21 \\
\hline Scott et al. (2000) & Biesieviei & South Africa & 580 & & 27.2 & 1298 & 593.6 & 100 \\
\hline Scott et al. (2000) & Bosboukloof & South Africa & 671 & & 200.9 & 1564 & 245.9 & 100 \\
\hline Scott et al. (2000) & Witklip-6 & South Africa & 1080 & & 165.3 & 929 & 259.7 & 100 \\
\hline Scott et al. (2000) & WitkliP-5 & South Africa & 1340 & & 108 & 929 & 261.7 & 51 \\
\hline Webb (2009) & Canobolas A & Australia & 1200 & & 55.3 & 1080 & 289 & 100 \\
\hline Webb (2009) & Canobolas B & Australia & 1180 & & 55.4 & 1080 & 247 & 100 \\
\hline Cosandey (1990) & Latte & France & & & 20 & 1900 & 1278 & 100 \\
\hline $\begin{array}{c}\text { Adams and Flower } \\
(2006)\end{array}$ & Maimai M5 & \multicolumn{2}{|c|}{ New Zealand } & Gritty silt loam & 2.31 & 2453 & 1578 & 100 \\
\hline $\begin{array}{c}\text { Adams and Flower } \\
(2006)\end{array}$ & Maimai M8 & \multicolumn{2}{|c|}{ New Zealand } & Gritty silt loam & 3.84 & 2453 & 1213 & 95 \\
\hline $\begin{array}{l}\text { Adams and Flower } \\
\text { (2006), Rowe et al. } \\
\text { (2002) }\end{array}$ & Glenbervie, Logbridge & \multicolumn{2}{|c|}{ New Zealand } & & 12.6 & 1920 & 830 & 100 \\
\hline $\begin{array}{l}\text { Adams and Flower } \\
\text { (2006), Rowe et al. } \\
(2002)\end{array}$ & Glenbervie, Pines & \multicolumn{2}{|c|}{ New Zealand } & & 15.5 & 1920 & 760 & 100 \\
\hline $\begin{array}{l}\text { Adams and Flower } \\
\text { (2006), Rowe et al. } \\
(2002)\end{array}$ & Moumoukai, Central & \multicolumn{2}{|c|}{ New Zealand } & Clay loam & 11.42 & 1690 & 660 & 100 \\
\hline $\begin{array}{c}\text { Komatsu et al. (2011), } \\
\text { Adams and Flower } \\
(2006)\end{array}$ & Moumoukai, South & \multicolumn{2}{|c|}{ New Zealand } & Clay loam & 14.98 & 1700 & 646 & 100 \\
\hline $\begin{array}{l}\text { Adams and Flower } \\
\text { (2006), Rowe et al. } \\
\text { (2002) }\end{array}$ & Purukohukohu, Puruki & \multicolumn{2}{|c|}{ New Zealand } & $\begin{array}{l}\text { Sandy loam to } \\
\text { loamy sand }\end{array}$ & 34.4 & 1590 & 540 & 100 \\
\hline $\begin{array}{l}\text { Adams and Flower } \\
\text { (2006), Rowe et al. } \\
(2002)\end{array}$ & Pakuratahi & \multicolumn{2}{|c|}{ New Zealand } & Silt loam & 345 & 1097 & 380 & 87 \\
\hline $\begin{array}{c}\text { Adams and Flower } \\
\text { (2006) }\end{array}$ & Moutere, C13 & \multicolumn{2}{|c|}{ New Zealand } & & 7.65 & 1010 & 64 & 100 \\
\hline
\end{tabular}

MAP: mean annual precipitation, MAS: mean annual streamflow, DF: deforestation, Elv.: elevation 